UDC: $37.034+177.72+159.913$

DOI: https://doi.org/10.24195/2414-4665-2017-1-7

\author{
Oksana Koval, \\ PhD (Candidate of Pedagogical Sciences), associate professor, \\ Department of Psychology and Social Work, Ternopil National Economic University, \\ 11, Lvivska Str., Ternopil, Ukraine
}

\title{
THE ACT OF MERCY AS A CANON OF MORAL FORMATION OF A PERSONALITY
}

The paper characterizes moral and psychological nature of mercy. The concept of mercy is analyzed in religious, ethical and philosophical, pedagogical, psychological views. Based on the theory of V. Romenets, canonical structure of an act is considered as cyclical succession of situational, motivational, active, and after-act components. The principal components of phenomenology of the act of mercy have been studied, namely: life situation, moral and sensuous experience caused by it, moral understanding of the situation and behavioural motives, choice and decision-making, volitional stimulus, act, after-act understanding. It is assumed that at the stage of after-act, every act of mercy causes ambivalent feelings in a person, which become the psychological basis for future acts.

Keywords: mercy, psychological nature of mercy, the act of mercy, canonical structure of the act of mercy, components of the canonical structure of the act of mercy.

\section{Introduction}

For a long time, mercy as a moral and ethical category traditionally has not been included to the conceptual apparatus of psychology. Moreover, in the Soviet Union, the term "mercy" was excluded both from scientific and official use being associated with religion, and therefore, it was regarded as a "relic of the past" and something unworthy for a Soviet person [11]. However, in people's minds and everyday life there has always been a place for both understanding the true meaning of this term, and demonstration of this virtue in personality's life.

With the emergence of the accidental situation in the Ukrainian society, which is destructive for human development and dangerous in its consequences (ATO, immigrants and refugees from Crimea and eastern Ukraine), the issue of the development of a moral personality endowed with ideals of good, who rejects actively destructive ideas, capable of resisting them and showing mercy, becomes really topical. Mercy is the virtue that characterizes a person in terms of spiritual self-expression in daily life and communication with others. This quality-trait helps a person to manifest compassion, tolerance, sympathy to others. Therefore, it is considered as one of supreme human values. In the light of changes in modern psychology, which in its academic pursuits refers to "highest phenomenological levels of human existence" [9, p. 176], studying the psychological nature of mercy is determined not only by research interests, but also by the current state of interpersonal relationships in the society. "Science is supposed to study uppermost manifestations of the existing phenomena. It is possible when human nature is revealed as fully as possible, at the highest possible level: in the brightest, purest and the most unique way. For a human being such an opportunity is associated with acts of mercy, a kind of acts for the sake of supreme human values and ideals. The act (including mercy) in its full expression will always be personality's spiritual de- velopment and work of moral values at the same time", claimed V. Romenets, the prominent Ukrainian psychologist, founder of the national historical and psychological sciences, and the author of philosophical and psychological theory of an act [17, p. 717].

The issue of mercy has rarely been the subject of research by psychologists; also hardly has personal mercy been regarded as an independent psychological category. Research studies were made on the phenomenon in religious $[5 ; 8 ; 13]$, ethical and philosophical $[10 ; 25]$, pedagogical $[1 ; 4 ; 26]$ aspects and in terms of social work $[12$; 14]. The philosophical basis of understanding the concept of mercy is found in the works of ancient philosophers: Aristotle, Confucius, Pythagoras, Plato, Socrates and others. They attributed this quality to the most important human virtues. As socio-cultural phenomenon, mercy was also included into the philosophical teachings of the world religions, including Christianity, where they were complemented with merciful love for one's neighbour, which was the core of the moral law for human society and the universal value that regulates social and interpersonal relationships. According to Christian teaching, in mercy one dedicates oneself to God and thus chooses the path of goodness, love, service to others and one's spiritual selfimprovement $[19 ; 20]$.

For centuries, mercy was regarded as an essential condition of human existence, but in the mid-20s of the twentieth century, the word "mercy" has been removed from general use, as such that did not meet the idea of class struggle in those years, and for more than half a century it could be found only in religious literature. Only in the mid-80s of the twentieth century it was again put into literary language, and then in active use. However, it significantly lost its original semantic volume, which was practically reduced to a semantic variant associated with the word "charity" [6]. 
In the post-Soviet period, scientific interest in the phenomenon of mercy increased, since some educators became concerned about increasing violent and vulgar pragmatism of the new generation and growing lack of spirituality. Theoretical basis of instilling mercy in children and its essence were considered in the writings of Sh. Amonashvili, V. Babenko, L. Bezhlasna, I. Bekh, O. Bohdanova, M. Boldyrev, O. Bondarevska, O. Buduhay, Yu. Hlinchuk, I. Kobylchenko, I. Kniazheva, O. Matviienko, N. Monakhov, A. Petrova, O. Savchenko, T. Sushchenko, A. Yakimov, and others.

In psychological science, the concept of mercy appeared only in the last decade following active development of moral rights awareness. B. Bratus wrote: "There is a gradual turn, if not to soul in its full sense, but to spirituality, human spiritual manifestation. ... The world of human emotions, experiences increasingly moves towards the centre of psychologists' interest. Scientific vocabulary has also changed. Finally, such concepts as mercy, compassion, love, hope, etc. were included into psychology again. After more than a century, psychology is associated with philosophy and ethics again, and under certain conditions of such correlation, it may become morally oriented" [6].

In contemporary philosophical (by I. Ilyin, V. Zenkovskyi, N. Losskyi, V. Rozanov, V. Soloviev, and others), and psychological (by B. Ananiev, I. Bekh, L. Bozhovych, B. Bratus, Yu. Vasyliuk, L. Vyhotskyi, Ye. Holovakha, V. Kunitsyna, K. Muzdybaiev, V. Mukhina, N. Panina, K. Rogers, H. Sviderska, V. Slobodchykov, S. Rubinshtein, D. Feldshtein, and others) conceptions, mercy is considered as characteristics of mental and purely spiritual health of an individual. The problem of moral development of a personality is revealed in the works of L. Antsiferova, L. Bozhovych, B. Bratus, Yu. Vasyliuk, L. Kohlberg, D. Leontiev, A. Maslov, G. Piaget, S. Rubinshtein, V. Frankl, E. Fromm

Many researchers are convinced that personality is fully and significantly expressed in an action. In modern psychology, an action is central and is seen as the foundation of the theory and history of psychology, as the centre of the psychic. In domestic studies of actions, the way of human living was researched by V. Bakhtin, I. Bekh, L. Bozhovych, M. Boryshevskyi, L. Vyhotskyi, H. Humnytskyi, M. Huseltseva, P. Miasoid, V. Romenets, S. Rubinshtein, V. Tatenko, T. Tytarenko, A. Skrypchenko, Ye. Subotskyi, Ye. Surkov, A. Furman, O. Furman.

Since the phenomenon of mercy has never been studied by psychologists as an independent psychological phenomenon, the aim of our research is to consider ontogenesis of an act of mercy in the moral formation of personality.

\section{Discussion}

Complete act is transcendence to a new dimension of life; it is always overcoming and transition to the new existential space; it is a new period, the beginning of a new era; it is transition to a qualitatively new life where the past is sometimes reduced to the intention of self-creation.
The way to an act is described in psychology in such an order: life situation - moral and sensory experience generated by it - moral awareness of the situation and motivation, choice and decision-making - volitional stimulus - act - after-act realization [18]. In this way, an act becomes the unity of situational, motivational, active, and after-act components, and the relation between these components is "viable both for an act and for a person who performs it" [18, p. 424-439].

Professor I. Bekh emphasizes that mercy is an act that expresses human feelings aimed at the other person's welfare. Such an act shows openness of one's inner world towards the others who are similar to oneself; otherwise the act cannot be committed [1, p. 218]. According to him, there are two types of such an act. The first one is the act, in which a person commits an act of kindness being motivated by experiencing compassion for another person. The second type is associated with justification, pardoning or forgiveness. Mercy as altruistic benefaction generates spiritual unity, when one person is so much concerned about the problem of another one that he/she temporarily identifies him-/herself with this person. This emotional feature plays an important role in interpersonal relationships, in perception of other people, and establishing mutual understanding [1, p. 218].

On the basis of the theory of V. Romenets about "Great Logics of an Act", which, according to A. Furman, "is a canonical structure of an act as cyclical succession of situational, motivational, active, and after-act components in intellectual projections onto the history of world psychology and many-sided phenomenology of human existence" [23], we are going to examine the basic components of the phenomenology of an act of mercy.

The situational aspect of an act is a unique combination of external and internal conditions that determine a certain form of activity of the individual (combination of social, individual, cultural and historical conditions, circumstances, events) [7, p. 196]. According to V. Romenets, "a situation is the highest level of the unity of environment dynamism and human passions" [18, p. 728].

It may have different dimensions, including psychological. Considering the genetic forms, professor V. Romenets finds it reasonable to distinguish between the psychological situations of the following types: pain and pleasure; the desirable and undesirable; threat and adventure; ideal, idyllic and lyrical; game and fairytale; situations of care, concern; stressful, fatal, dramatic, tragic or comic situations, etc. [18, p. 120]. It is also reasonable to distinguish "collision situation". In the case of an act of mercy, a person is "torn" between aspiration contradictions, and has to rise over those contradictions, to overcome them, to subordinate their contradictory objective nature to his/her own intentions.

Hence, in psychological understanding, the situation of an act of mercy will be regarded as: 1) the environment, surrounding people, circumstances, objective conditions that a person faces, which resist him/her in their autonomous existence; 2) personal circumstances that put 
together human inner existence; 3) the process and outcome of human transcendence beyond the external and personal circumstances and making them the conditions for development and implementation of an act under study. In other words, being in a certain situation, a person studies it, identifies him-/herself in it, and then turns this situation into a platform for the act of mercy.

A specific psychological mechanism and the result of human self-identification in a situation is motivation. V. Romenets wrote that "motivation is aimed at overcoming the conflict nature of a situation and making a decision to act in a certain way" $[15$, p. 121]. The scientist regards motivation conflict as a psychological core for motivation and the actual mechanism for transforming the situation. The motive that is more consistent with one's moral ideal will become of priority. The presence of a moral ideal makes it possible to understand and feel the internal unity of one's freedom and responsibility for one's own actions in a particular situation, the acts of mercy in our case.

The key element in the phenomenon of mercy (by B. Ananiev) is the ability to love and sympathize with people (empathy). In our opinion, they are the most significant in motivation for the act of mercy; and the derivatives are care for other people, recognizing the value of another person, sincerity, tolerance to others, formed ideas about the nature of mercy. In psychological studies empathy is seen as a person's ability to respond to the emotional experiences of others, as a kind of sensual process that is a three-level chain in its genetic aspect (compassion - sympathy - internal collaboration) (L. Strielkova), as penetration into the one's emotional state, where compassion and sympathy are different forms of its expression (A. Petrovskyi), or as the ability to perceive the feelings of another person as one's own, ability for emotional response as a fundamental component of communication and specific means of knowledge a human (Yu. Trofimov). It is important that the development of empathy depends not only on interaction with other people, but on the personal importance of these people for a particular person. The limited number of people that a person is likely to compassion not only blocks emotional sensitivity, but in some cases may turn into violence.

According to I. Bekh, humanity as a criterion of highly moral personality is a strategic benchmark in forming a sense of another person's value. The process of its formation may be different. In one case, humanity is formed as a reaction to brutality, either one's own or other's. In another case, humanity may be and should be developed as a sense of mutual humanity: firstly - towards oneself, and after a while - towards other people. Generally, there are two ways of teaching others to appreciate another person: either by demonstrating another person's merits or by a warning about disrespect for him/her [3, p. 56]. Russian researcher M. Mchedlov notes that mercy is associated with the attitude of an individual towards a challenging situation, physical and mental han- dicaps, and weaknesses of others together with the readiness to help them [12, p. 347]. Therefore, most scientists acknowledge sympathy as a component of mercy. However, according to V. Malakhov, mercy "does not require compassionate attitude towards others, although may include it. At the same time, to maintain its appropriate high moral level, mercy should be associated with tolerance and respect for each of its recipient; otherwise it loses its positive spiritual sense" [10, p. 345]. It is obvious that mercy should not be regarded as an expression of sympathy only, because they do not always mean the same in their existential cores. "If empathy is associated with one's concerns about others' sufferings, and devoting one's Self to others, compassion, on the contrary, involves a clearly defined person who does good to others who are different from him/her being guided by moral ideas, though not without emotional affection towards them" [10, p. 344].

The motivational conflict may gravitate to "fatalism" - depending on circumstances, and the "voluntarism" neglecting the circumstances. Besides, motivational conflict should be regarded as a process that may be manageable by a person, or happens spontaneously and becomes personal due to its internal nature. This raises more generalized problem of to what extent and in what sense a person becomes the subject of his/her own act. These ontopsychological problems were solved by professor $\mathrm{V}$. Romenets from the perspective of human priority and ability to dominate over circumstances.

For example, euthanasia is a consciously and intentionally committed act by a medical professional upon repeated and categorical request of a terminally ill patient to end his/her physical suffering that will end up in death. Many countries, namely Netherlands, Belgium, Finland, Sweden and others, tend to legalize euthanasia. The main and fundamental human right is the right for life. However, along with that there is the right to manage one's own life. It can be also interpreted as the right to expose it to a significant risk, or even decide on its termination. This particular issue generates much discussion. It is the right for life or death that has been the subject of discussion for lawyers, psychologists, physicians, and public for many years. The problem is whether euthanasia is a mercy or a crime? What motivates people to agree to commit such an act?

Ye. Surkov and V. Fadeyev emphasized that an act is a deliberate action associated with moral consciousness of an individual. The act of mercy primarily depends on one's attitude towards the environment, surrounding people, society, nature, oneself as an active subject. Motivation as personal characteristics of an individual is at the centre of I. Bekh's conception of determining what an act is: "An act is a certain motivation, personal quality, individual's active self-expression" [2, p. 247]. The acts of a morally developed personality are the result of free choices, and, therefore, he/she has a chance of making a mistake or being criticized by others. The acts that are motivated by various external reinforcements (incentives or penalties) are not involved into the essential characteris- 
tics of a morally developed personality. The first ones strengthen human character, evokes the sense of responsibility and independence, accelerate formation and test one's existing moral characteristics for viability, which is opposite to following suggested regulations, compliance with which is controlled. We only emphasize that the sense of independence and ability to take risks are not self-sufficient conditions for the formation of human morality.

An act it is socially controlled behavioural act generated by conscious motives. Contrary to impulsive actions, it complies with a certain intention and is equal to the action that is subject to the motives and aims of activity. It actually reveals personality with his/her priorities, attitude to the environment, characterological, and temperamental properties, etc. The act brings up such traits as perseverance, hypocrisy, honesty, isolation and others.

We assume that in the act of mercy that is performed on basis of scientific guess, certain outlook, there is also a component of faith. Faith is an assumption made by a person beyond logical proof. No matter how science has expanded, it always points out at something infinite and unknown that an act should relate to. That is why it always has some risk. A person sets everyday tasks that go beyond technical means of an act. But otherwise neither its technique nor ideology is developed. A child in attempt to learn how to walk cannot yet estimate his/her real chances and difficulties in achieving the goal, but relies on his/her will and the natural capacity. Therefore, the goal of an act is always beyond its actual technical, activity-related means.

The motivation of the prevailing act is integrated into corresponding deeds related to the act that, according to professor $\mathrm{V}$. Romenets is not equal to an instantaneous act, but involves at least two realization stages. The first stage is preparatory. A person always prepares mentally for implementation of an act. Subjective willingness to act forms an idea of what to make. It generates psychological modelling of an act performance including its possible consequences. Readiness to commit an act is approved by the fact that some subsequent event is not just a condition but the motive for it. "Motive for an action completes the cause-and-effect chain for a certain act - and the act is committed" $[15$, p. 766$]$. It is only to be noted that this "preparation" is done by a person him-/herself, keeping the status of a subject in the act. The way of one's acting behaviour is formed, showed and modified throughout life, gradually gaining sustainability in the process of committing [23, p. 36].

Mercy has always been a typical feature of Ukrainian people down the ages. For example, the acts of mercy, namely, redemption of citizens of ancient Rus from Greeks' captivity at the expense of the Treasury of the Princes Oleg and Igor were mentioned in the ancient agreements. With adoption of Christianity in Kievan Rus, caring for the poor became a Christian commitment. Churches and monasteries became centres of social assistance and generous support for the needy and misfor- tuned, providing them with money and food, healing the sick and teaching the poor and orphans. Yaroslav the Wise built a school for orphans in Novgorod at his own expense; knyaz Mykola Chernihivskyi founded a monastery hospital in Kyiv where the known physician Petro Syrotin worked on a voluntary basis; many brotherhoods were involved in building hospitals; a great number of Ukrainian Hetmans left a significant contribution to the history of charity and philanthropy. One of the most known types of communal assistance in rural Ukraine was "toloka" (free assistance to fire victims and construction developers, etc.). During the thirties and forties, a number of philanthropic associations were established in major cities. Charity was normal for manufacturers, merchants, intellectuals and officials. The revival of charity traditions in independent Ukraine caused active development of volunteer movement based on compassion and altruism [24]. It is especially important today, in the context of the current political situation in the country. Volunteering covers traditional forms of mutual assistance and selfassistance carried out for social benefit and with no material reward. Volunteer groups and initiatives mostly arise spontaneously through good will and desire to express support by helping people in need. It clearly shows a return to Christian values and mercy.

The most striking psychological phenomena that are revealed when performing of the act of mercy are selflessness and dedication. According to professor V. Romenets, they may reach the level of ecstatic tension. The ecstasy of self-forgetfulness accompanying the act makes it possible to withstand the most severe challenges and sufferings one may face. The act of mercy is not limited to recognition of other's values. It involves providing others with life and self-fulfillment opportunities on the basis of active commitment. Active help to others and remaining true to oneself make the act of mercy complex and provide it with meaning, no matter whom this help is addressed to [15, p. 345].

Does an act end with completion of the action? Answering this question, professor V. Romenets turned to the Biblical saying: "Ye shall know them by their fruits". It reveals the need for awareness of one's action together with assessment of its consequences both for oneself and for others.

What are the consequences for a person after completion of an act? One of the possibly suggested is related to positive emotions and feelings due to satisfaction of the relevant need and achieving the set goal. Another, by contrast, may force to think critically and admit that the committed act was only one of many possible activity vectors and it negated many other potential trajectories of individual existence. Therefore, we assume that every act of mercy performed during after-act stage causes personality's ambivalent feelings that eventually become a psychological basis for future acts. Professor V. Romenets links the possibility of internal satisfaction during after-act stage with its tendency to self-sacrifice as the highest goal and ontological value. He notes that all moral values and laws have already been revealed, and maintaining them gives sense to human life. One 
should not just be active but act. Human creativity has always existed and hopefully will exist in human acts. Therefore, everyone must be conscious of his/her mission in the world and ready to sacrifice for the sake of existing of all the alive, moral, spiritual, and human existence in particular.

Conclusions and prospects for further research

Thus, genesis of behaving mercifully involves one's self-identification in the situation, considering the available external and internal priorities and dependencies, conflicts with oneself and other people, and in such away a person can recognize personal priorities for one's authentic being. It is followed by motivational conflict that has to be overcome by an individual with the choice of the most important motive, defining primary objectives

\section{ЛIТЕРАТУРА}

1. Бех І. Д. Виховання особистості : Сходження до духовності / І. Д. Бех. - К. : Либідь, 2006. - 272 с.

2. Бех І. Д. Виховання особистості : У 2 кн. Кн. 1 : Особистісно-орієнтовний підхід : теоретико-технологічні засади / І. Д. Бех. - К. : Либідь, 2003. - 280 с.

3. Бех І. Д. Формувати у дитини почуття цінності іншої людини / І. Д. Бех // Педагогіка толерантності. 2001. - № 2. - С. 52-58.

4. Білоусова В. О. Теорія і методика гуманізації відносин старшокласників у позаурочній діяльності загальноосвітньої школи: Монографія. - К. : IЗМН, 1997. - 192 c.

5. Бог багатий милосердям. Dives in misericordia: Енцикліка вселенського архієрея Івана Павла II. Львів : Місіонер, 1999. - 64 с.

6. Глухова И. Милосердие как экзистенциальный ресурс личности [Эл. ресурс]. - Режим доступа : http://hpsy.ru/public/x6109.htm

7. Гуменюк О. С. Психологія впливу Монографія / O. С. Гуменюк. - Тернопіль Економічна думка, 2003. - 304 c.

8. Кальстер С. «Будьте милосердні, як і Отець ваш милосердний» // Сопричастя. - Львів : Свічадо. 2005. - № 1-2. - С. 24-35.

9. Кириленко Т. С. Чуттєво-емоційні виміри вчинковості. Людина - Суб'єкт - Вчинок: Філософсько-психологічні студії / Т. С. Кириленко. К. : Либідь, 2006. - С. 176-196.

10. Малахов В. Милосердя / Малахов В. - К. : Либідь, 2001. - С. 344-346.

11. Милосердие. Настольная книга священнослужителя: [в 6 т.]. - Т.6. - Тематический материал для проповеди. Евхаристия - Молитва. - М., 1988. С. 308-326.

12. Милосердие. Учебное пособие / Под ред. М. П. Мчедлова. - М. : Российская политическая энциклопедия (РОССПЭН), 1998. - 214 с.

13. Міцкевич Ф. Блаженні милосердні / Ф. Міцкевич // Сопричастя. - Львів : Свічадо. - 2005. - № 1-2. - C. 3-14.

14. Морозова Н. С. Детское милосердие как одно из направлений социальной работы / Н. С. Морозова // and the rejecting of all the secondary ones. The next stage involves achievement of the planned. And the last stage is to give it an honest assessment to the performed act and to develop a new instruction for future acts.

John Paul II calls the act of mercy love that is more powerful than sin. Mercy as the infinite perfection of God is endless and is revealed when it "sees, assists and produces good of any evil that exists in the man and the world" [5, p. 24].

The article does not cover the diversity of theoretical and practical search for the solution of problem. Prospects for further scientific studies may involve further study of psychosophy of the act of mercy in view of the cycled-act approach.

Теория и практика социальной работы : отечественный и зарубежный опыт. - М., 1991. - Т. 1. - 272 с.

15. Психологія вчинку : Шляхами творчості В. А. Роменця : зб. ст. / упоряд. П. А. М'ясоїд; відп. ред. А. В. Фурман. - К. : Либідь, 2012. - 296 с.

16. Роменець В. А. Історія психології ХХ століття : навч. посіб. / В. А. Роменець. - К. : Либідь, 2007. $832 \mathrm{c}$.

17. Роменець В. А. Історія психології ХХ століття / В. А. Роменець, І. П. Маноха. - 2-ге вид., стер. - К. : Либідь, 2003. - 992 с.

18. Роменець В. А. Історія психології ХХ століття / В. А. Роменець, І. П. Маноха. - К. : Либідь, 1998. 992 c.

19. Свідерська Г. М. Морально-психологічна природа феномену милосердя / Г. М. Свідерська // Пробл. заг. та пед. психології : зб. наук. пр. - 2011. 13, Ч. 4. - С. 343-350.

20. Свідерська Г. М. Психологія чуйності : монографія / Г. М. Свідерська. - Т. : ТНПУ, 2013. $305 \mathrm{c}$.

21. Фурман А. А. Психологія особистості : ціннісно-орієнтаційний вимір : [монографія] / Анатолій Анатолійович Фурман. - Одеса : ОНПУ; Тернопіль : ТНЕУ, 2016. - 312 с.

22. Фурман А. В. Володимир Роменець як методолог психософійного духу / А. Фурман // Психологія і суспільство. - 2011. - № 2. - С. 39-50.

23. Фурман А. В. Психософія вчинку В. А. Роменця як методологія пізнання людського буття / A. В. Фурман // Методологічний альманах «Вітакультурний млин» : зб. наук. праць. - 2016. - С. $21-31$

24. Фурман А. В., Підгурська М. В. Історія соціальної роботи : [навчальний посібник] / Анатолій Васильович Фурман, Марія Василівна Підгурська. Тернопіль : ТНЕУ, 2014. - 174 с.

25. Человек. Мыслители прошлого и настоящего о его жизни, смерти и безсмертия / П. Гуревич. - М., 1991. - C. 24. 
26. Шутова В. Воспитание милосердия (педагогическая мастерская для родителей) / В. Шутова //

\section{REFERENCES}

1. Bekh, I. D. (2006). Vykhovannia osobystosti: Skhodzhennia do dukhovnosti [Educating personality: Climbing to spirituality]. Kyiv: Lybid [in Ukrainian].

2. Bekh, I. D. (2003). Vykhovannia osobystosti: Osobystisno-orientovanyi pidkhid: teoretyko-tekhnologichni zasady [Educating personality: Personality-oriented approach: theoretical and technological bases]. Kyiv: Lybid [in Ukrainian].

3. Bekh, I. D. (2001). Formuvaty u dytyny pochuttia tsinnosti inshoii liudyny [To form a child's sense of another person's value]. Pedagogika tolerantnosti - Pedagogy of tolerance, 2, 52-58 [in Ukrainian].

4. Bilousova, V. O. (1997). Teoriia i metodyka humanizatsii vidnosyn starshoklasnykiv $u$ pozaurochnii diialnosti zahalnoosvitnoi shkoly [Theory and methods of humanizing senior school students' relations during extracurricular activities]. Kyiv: IZMN [in Ukrainian].

5. Boh bahatyi myloserdyam. Entsyklika vselenskogo arkhiiereia Ivana Pavla II [Merciful God. Dives in misericordia: universal bishop Encyclical of John Paul II]. (1999). Lviv: Misioner [in Ukrainian].

6. Glykhova, I. (n.d.). Miloserdie kak ekzistentsialnyi resurs lichnosti [Mercy as existential personality resource]. Retrieved from: http://hpsy.ru/public/x6109.htm [in Russian].

7. Humeniuk, O. Ye. (2003). Psykholohiia vplyvu [Psychology of influence]. Ternopil: Ekonomichna dumka [in Ukrainian].

8. Kalster, S. (2005). Budte myloserdni yak i Otets vash myloserdnyi [Be merciful, as your Father is merciful]. Soprytchastia - Communion, 1-2, 24-35. Lviv: Svitchado [in Ukrainian].

9. Kyrylenko, T. S. (2006). Chuttievo-emotsiini vymiry vchynkovosti [Sensory-emotional dimensions of acts]. Filosofsko-psykhologichni studii - Philosophical and psychological studies, 176-196. Kyiv: Lybid [in Ukrainian].

10. Malakhov, V. (2001). Myloserdia [Mercy]. Kyiv: Lybid [in Ukrainian].

11. Miloserdiye. Nastolnaya kniga svyacshennoslyszytelya [Mercy. Handbook of a priest]. (1988). Moscow [in Russian].

12. Mchedlov, M. P. (Ed.). (1998). Miloserdiye [Mercy]. Moscow: Rossiiskaya politicheskaya entsiklopediya [in Russian].

13. Mitskevich, F. (2005). Blazhenni myloserdni [Blessed are the merciful]. Soprychastia - Communion. Lviv: Svitchado [in Ukrainian].

14. Morozova, N. S. (1991). Detskoye miloserdie kak odno is napravleniy sotsialnoy raboty [Children's mercy as one of the areas of social work]. Teoriya i prak-
Воспитание школьников. - 2004. - № 6. - С. 33-36.

tyka sotsialnoi raboty: otechestvennyi i zarubezhnyi opyt - Theory and practice of social work: domestic and foreign experience, 1. Moscow [in Russian].

15. Miasoid, P. A., \& Furman, A. V. (Eds.). (2012). Psykholohiia vchynku: shlyakhamy tvortchosti $V$. A. Romentsya [Psychology of an act: studying the works of $V$. Romenets]. Kyiv: Lybid [in Ukrainian].

16. Romenets, V. A. (2007). Istoriya psykholohii XX stolittia [History of psychology of the twentieth century]. Kyiv: Lybid [in Ukrainian].

17. Romenets V. A., \& Manokha I. P. (1998). Istoriya psykholohii $X X$ stolittia [History of psychology of the twentieth century]. Kyiv: Lybid [in Ukrainian].

18. Romenets, V. A., \& Manokha, I. P. (2003). Istoriya psykholohii XX stolittia [History of psychology of the twentieth century]. Kyiv: Lybid [in Ukrainian].

19. Sviderska, H. M. (2011). Moralnopsykholohichna pryroda fenomenu myloserdya [Moral and psychological nature of the phenomenon of mercy]. Problemy zahalnoi ta pedahohichnoi psykholohii - Problems of general and educational psychology, 13, 343-350 [in Ukrainian].

20. Sviderska, H. M. (2013). Psykholohiia chuinosti [Psychology of sensitivity]. Ternopil: TNPU [in Ukrainian].

21. Furman, A. A. (2016). Psykholohiia osobystosti: tsinnisno-orientatsiinyi vymir [Personality psychology: valueorientation dimension]. Ternopil: TNEU [in Ukrainian].

22. Furman, A. V. (2011). Volodymyr Romenets yak metodoloh psykhosofiinoho dukhu [Volodymyr Romanets as a methodologist of psychosophical mind]. Psykhologiya i suspilstvo - Psychology and society, 2, 3950 [in Ukrainian].

23. Furman, A. V. (2016). Psykhosophiya vchynku yak metodolohiya piznannia ludskoho buttia [Psychosophy of an act as a methodology of knowing a human being]. Metodolohichnyi almanakh «Vitakulturnyi mlyn» - Methodological almanac «Vitacultural mill», 21-31 [in Ukrainian].

24. Furman, A. V., \& Pidhurska, M. V. (2016). Istoriia sotsialnoi roboty [History of social work]. Ternopil: TNEU [in Ukrainian].

25. Chelovek. Mysliteli proshloho i nastoyascheho o yego zhizni, smerti i bessmertii [A man. The thinkers of the past and present about human life, death and immortality]. (2016). Moscow. [in Russian].

26. Shutova, V. (n.d.). Vospitaniye miloserdiya (pedagogicheskaya masterskaya dlya roditelei) [Instilling mercy (pedagogical workshop for parents)]. Vospitaniye shkolnikov - Education of schoolchildren, 6, 33-36 [in Russian]. 
Оксана Свгенї̈на Коваль, кандидат педагогічних наук, доцент кафедри психологї та соціальної роботи, Тернопільський національний економічний університет, вул. Львівська, 11, м. Тернопіль, Украӥна

\section{ВЧИНОК МИЛОСЕРДЯ ЯК КАНОН МОРАЛЬНОГО СТАНОВЛЕННЯ ОСОБИСТОСТІ}

3 огляду на те, що проблема милосердя досі вкрай рідко була предметом дослідження психологів, а особистісне милосердя майже не розглядалося як самостійна психологічна категорія, у статті схарактеризовано морально-психологічну природу милосердя; здійснено ретроспективний аналіз поняття «милосердя» у світлі релігійної, етико-філософської, педагогічної, психологічної позицій та в аспекті соціальної роботи. Дослідження мало на меті вивчити проблему онтогенезу вчинку милосердя у процесі морального становлення особистості. Базуючись на вченні В. А. Роменця про «Велику логіку вчинку» як канонічну структуру вчинку в циклічній наступності ситуаційного, мотиваційного, діяльного і післядіяльного компонентів в інтелектуальній проекції на історію всесвітньої психології і феноменологію людського буття, здійснено спробу дослідити основні складові феноменології вчинку милосердя, зокрема: життєву ситуацію, породжене нею моральночуттєве переживання, моральне усвідомлення ситуації та мотивів поведінки, вибір і прийняття рішень, вольовий стимул, учинок, постдійове усвідомлення. Визначено, що онтогенез учинкової активності милосердя полягає в тому, щоб, визначившись у ситуації життєдіяльності, зваживши на наявні зовнішні та внутрішні пріоритети й залежності, конфліктні чи навіть колізійні стосунки з оточенням і самою собою, людина з'ясувала те, що їй потрібно для автентичного буття. Ситуаційний аспект учинку - своєрідне поєднання зовнішніх і внутрішніх умов, що зумовлюють певну форму активності особистості - вчинкової активності. На етапі боротьби мотивів людина обирає найзначущіше, визначається у головній меті й відкидає все другорядне. Доведено, що тільки наявність морального ідеалу дає їй змогу зрозуміти й відчути в конкретній ситуації внутрішню поєднаність своєї свободи з відповідальністю за вчинки милосердя. Мотив учинку, який переміг, втілюється у відповідній учинковій дії на двох етапах: підготовчому і оцінному. Здійснено припущення, що кожен здійснений учинок милосердя на етапі післядії викликає у людини амбівалентні почуття, які стають психологічним підгрунтям для наступних таких учинків.

Ключові слова: милосердя, психологічна природа милосердя, вчинок милосердя, канонічна структура вчинку милосердя, компоненти канонічної структури вчинку милосердя.

Submitted on January, 19, 2017

Reviewed by: Doctor of Psychology, prof. Anatolii Furman 